\title{
Developing Shopping Abilities to Empower: An Ethnography of Moroccan Women in Supermarkets
}

Delphine Godefroit-Winkel

Toulouse Business School, Casablanca

Follow this and additional works at: https://digitalcommons.uri.edu/mgdr

Part of the Marketing Commons, and the Social and Behavioral Sciences Commons

\section{Recommended Citation}

Godefroit-Winkel, Delphine (2018) "Developing Shopping Abilities to Empower: An Ethnography of Moroccan Women in Supermarkets," Markets, Globalization \& Development Review. Vol. 3: No. 2, Article 2. DOI: 10.23860/MGDR-2018-03-02-02

Available at: https://digitalcommons.uri.edu/mgdr/vol3/iss2/2

This Article is brought to you for free and open access by DigitalCommons@URI. It has been accepted for inclusion in Markets, Globalization \& Development Review by an authorized editor of DigitalCommons@URI. For more information, please contact digitalcommons-group@uri.edu. 
Developing Shopping Abilities to Empower: An Ethnography of Moroccan Women in Supermarkets

\section{Cover Page Footnote}

The author would like to thank the reviewers and editors for their constructive comments. 


\section{Markets, Globalization \& Development Review}
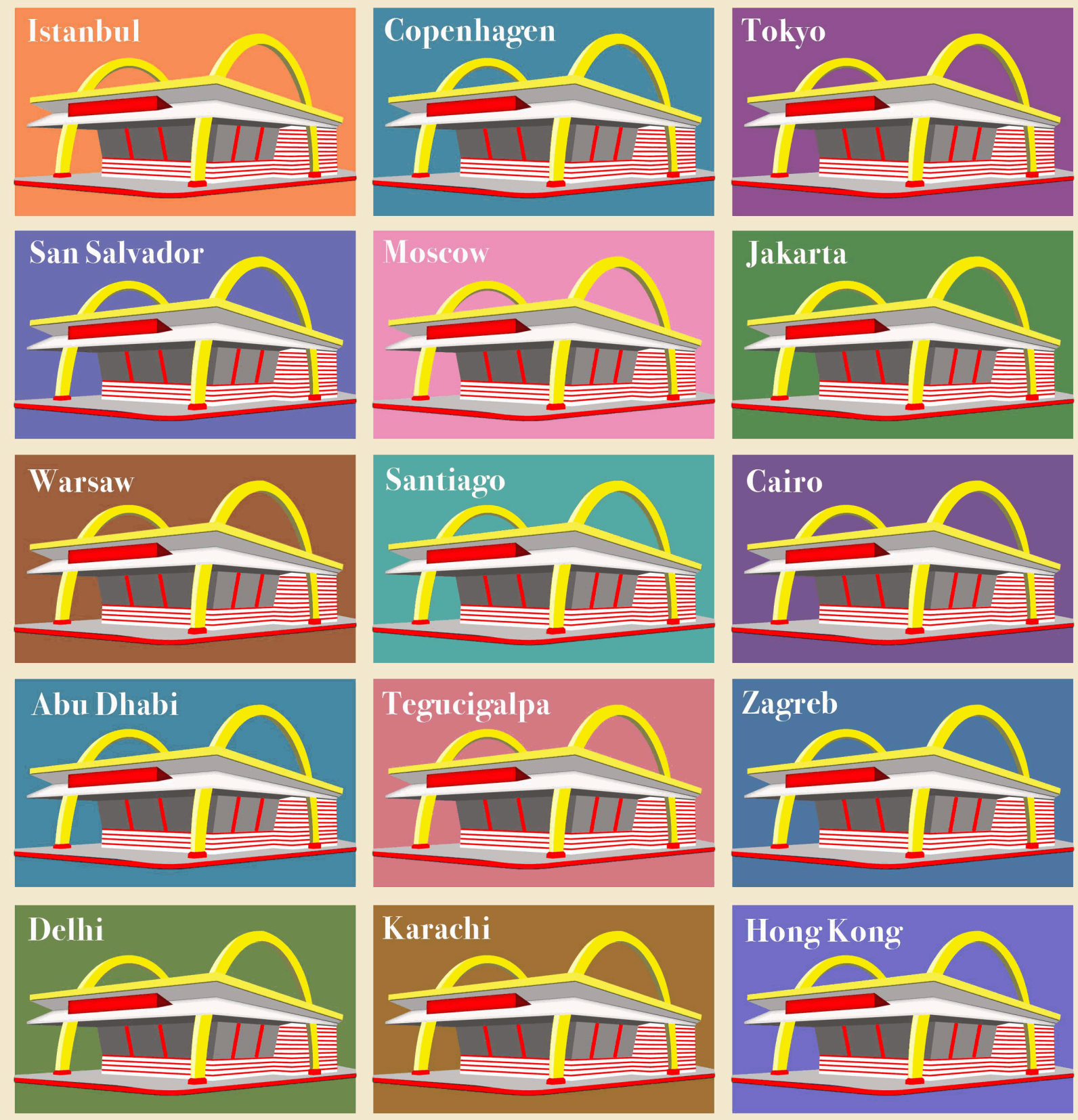

This article is available in Markets, Globalization \& Development Review: https://digitalcommons.uri.edu/mgdr/vol3/ 


\section{Developing Shopping Abilities to Empower: An Ethnography of Moroccan Women in Supermarkets}

\section{Introduction}

Most institutions recognize the importance of women's empowerment in social development. The United Nations, for instance, recognizes that women's contributions and leadership are essential to improving sustainability in developing nations. They have set gender equality as one of the top five priorities of their sustainable development program. The Arab Human Development Report of the United Nation Development Program in 2005 highlighted the central role of women in the Arab world. Although Arab women have made great strides, they still face numerous impediments though. In this article, we examine how Arab women acquire new abilities in the market and how they use such abilities to gain power in their families and communities.

We define women's empowerment as the capacity to make strategic choices about matters that previously have been denied (Malhotra et al. 2009). Our approach distinguishes from traditional perspectives, which emphasize women's empowerment through literacy, education, and training (e.g., Alvarez and Lopez 2013; Bayeh 2016; UNDP 2016). Indeed, observations from the field suggest that education may not be sufficient to empower the Arab women. For instance, national statistics from Arab states reveal that even if women tend to earn better scores at school than their male counterparts, and though gender parity exists in many Arab universities, for cultural reasons, most educated women do not enter the job market (UNDP 2005). In the contemporary Arab collective imagination, a man fits better than any woman in any paid job (UNDP 2005). Moreover, local cultural impediments limit avenues for women to gain forms of power other than marriage and procreation (Mernissi 2010). In Arab contexts, education for girls is often viewed as a way to ensure a good marriage; an educated bride is an asset who provides a good education for the children (Sadiqi 2003). In this context, only $34.3 \%$ of Moroccan women with a university degree have paid jobs (HCP 2013), about 100,000 Moroccan women quit the job market each year to stay home and commit to household activities. Overall, the female labor rate in Morocco is decreasing (HCP 2013), from 28.1\% in 2000 to $25.1 \%$ in 2013 (CNDH 2015). 53\% of women cannot work for family reasons (World Bank 2015), namely, because parents/husbands do not 
allow it, and women obey their male counterparts. Furthermore, $9 \%$ of Moroccan women are deprived of any form of decision making (Ministère de la Santé 2005).

Overall, the majority of Moroccan women are outside the public arena. The dominant discourse delegitimizes their presence in public spaces (CNDH 2015) and severely infringes women's public visibility and expression (Sadiqi 2003). Thus, most attempts to boost Arab women's power in families and communities through literacy, education, or training seem to have been insufficient. There is a need for a better understanding of additional avenues for Arab women's empowerment. In such a context, the market may be an option; it has long been regarded as a place of social mutation and transgression (e.g., Firat and Venkatesh 1995; Kapchan 1996).

Accordingly, we ask: How can Arab women empower in the market? Our argument is that Arab women may become empowered through the development of shopping abilities, which we define as consumer skills or proficiencies to process information in shopping situations.

For a long time, Arab women have been denied access to markets (Kapchan 1996). In most developed countries, household provisioning is a female activity (e.g., Falk and Campbell 1997), but in many developing countries, most women have no direct access to the marketplace, as is the case in Arab contexts, where men are responsible for shopping (Bourdieu 1980). However, an increasing number of female customers are patronizing recently opened Arab supermarkets without male chaperones (Amine and Lazzaoui 2010; Sehib, Jackson and Gorton 2012). This phenomenon not only opens doors to mutations of power within families and communities but also raises questions about women's ability to shop: How do women achieve shopping access to a supermarket? What are the difficulties? Which abilities do they develop?

Given that household provisioning is a male activity in Arab contexts, female Arab shoppers enter a male domain. This activity also raises questions about the distribution of power. Previous consumer literature has suggested that the acquisition of new power takes place through globalized forms of retailing (e.g., shopping malls, supermarkets). For instance, Varman and Belk (2012) show that local consumers feel empowered and modern in Indian shopping malls. Dholakia and Sinha (2005) observe that Indian shoppers like to speak Hindi or English not only to supermarket employees but also among themselves, even when the normal flow of their discussion would be in Gujarati. Speaking English or Hindi gives them more power in the eyes of significant others. Amine and 
Lazzaoui (2011) describe the "bricolages" created by lower classes to upgrade their self-images in supermarkets. In contrast, Ozgun, Yurdakul and Atik (2017) show that poor Turkish women avoid shopping malls when they do not have enough purchasing power. Although these studies provide interesting grounded approaches to power plays in globalized forms of retailing, they also assume that shopping is an easy task. To the best of our knowledge, no studies have focused on the difficulties experienced by local shoppers trying to navigate globalized forms of retailing.

Our research thus extends previous work on the dynamics between global and local. According to Firat (2016), marketing can be defined as "the design and facilitation of processes that empower individuals, who through their communities, seek to achieve development." In this study, we seek to understand how local consumers gain power through the spread of globalized forms of retailing.

Moreover, our work complements knowledge about the participation of the poor and illiterate in development (e.g., Achrol and Kotler 2016). It examines the shopping strategies and abilities of poor, illiterate Moroccan women as well as rich, educated Moroccan women. The results reveal that both rich and poor have distinct shopping experiences and objectives, but they also share similar issues in terms of shopping abilities. By examining the relationship of consumer abilities with empowerment, we extend previous research on social development.

Further, we also suggest the effects of women empowerment at the macro level. Shopping women increase their impact on the demand for a wide variety of goods. They may decide on the future of many businesses: which brands will be successful, which producer will increase his profitability, and which sector of activity will flourish.

This article is organized as follows: We review literature on consumer abilities and empowerment, then describe our research site and methodology and detail our findings. Finally, we make two theoretical suggestions: We contend that consumers develop specific empowering abilities, outside of traditional education or training programs, and that such abilities arise from the spread of globalization and new forms of retailing. We also propose that consumer vulnerability should be reconsidered. Local consumers in developing contexts, rather than being vulnerable, have abilities to become empowered through the market. Our proposals in turn suggest avenues for further research. 


\section{Literature Review}

In this section, we review literature on consumer abilities in the context of household provisioning and describe recent work on empowerment and consumer vulnerability.

\section{Consumer Abilities in Household Provisioning}

Household provisioning is a serious cognitive activity that requires a strong set of skills, including mathematical problem solving (Anteblian and Barth 2011; Viswanathan, Rosa and Harris 2005). Shopping difficulties are masked by repeated purchases that often end with the same set of purchased goods (Lave, Murtaugh and de la Rocha 1984).

General discourse in developed countries denigrates the complexity of the task (Miller 1998). The difficulty is increased in supermarkets, for shoppers are usually alone, with direct access to products (Abbes and Barth 2011). Shopping in supermarkets with selfservice differs greatly from shopping in traditional stores, where customers benefit much from the help of store employees (Goldman 1974). The complexity of shopping derives from the great amount of information available and shoppers have to identify alone which parts are relevant to them (Lave, Murtaugh and de la Rocha 1984).

The information varies in nature. Quantitative information refers to taste, nutritional value, or design (e.g., Viswanathan, Hastak and Gau, 2009). Quantitative information includes price, or volume specifications. Shoppers use arithmetic when making comparisons (Lave, Murthaugh and de la Rocha 1984). Along with making qualitative decisions, they make calculations to reduce the number of alternatives and choose single items (Walser-Luchesi 2011). At time of purchase, shoppers must be able to calculate their overall expenses and check that the expenses match their budgets. Whenever expenses exceed expected or affordable budgets, shoppers must make final mathematical resolutions to select which items stay in their trolley.

The forgoing discussion demonstrates that shopping is a succession of small processes that are dialectically constituted, in which problems systematically pop up and are solved. It is not surprising that specific abilities are needed to perform household provisioning. In the next section, we examine how major development institutions portray such abilities.

\section{Consumer Abilities and Vulnerability}

Consumers' abilities to make proper decisions about household provisioning have an impact on their health and wellbeing (Palumbo 
2016). Both institutional reports and literature identify the inability to shop as a characteristic of functionally illiterate consumers (e.g., Brennan et al. 2017). The European Union (EU), United Nations Educational, Scientific and Cultural Organization (UNESCO), Organisation for Economic Cooperation and Development (OECD), and UN Environment Programme (UNEP) have identified a set of core abilities as fundamental to navigating the market. The EU has devised a program to help vulnerable consumers (e.g., children, migrants, seniors) acquire specific abilities to navigate in the market. The aim of the program is to help vulnerable consumers understand and evaluate products and properly manage their personal wellbeing. For instance, consumers should be able to identify information displayed on products and be aware of quality, reliability, security, and test modes. Overall, consumers should have a strong capacity for abstract manipulation and the ability to build a variety of scenarios. In such approaches, the focus is on consumer vulnerability and negative outcomes; education is regarded as a unique means to increase wellbeing. However, such perspectives tend to underestimate consumers' abilities to cope with difficult decision-making situations.

An alternative approach suggests that illiterate consumers develop specific coping strategies to compensate for their illiteracy. This approach is described in literature on functionally illiterate consumers, which defines functional illiteracy as a level of reading and writing skills that is inadequate to manage daily living. Functional illiteracy differs from illiteracy, which is the inability to read or write in any capacity. Although academic study of consumer functional illiteracy is scarce (e.g., Wallendorf 2001), work by Viswanathan, Rosa and Harris (2005) has uncovered specific cognitive predilections, decision rules, trade-offs, and coping mechanisms practiced by illiterate U.S. consumers in supermarkets. They find that at the cognitive level, functionally illiterate consumers display concrete reasoning and pictographic thinking rather than abstract and conceptual thinking (Viswanathan, Rosa and Harris 2005). Concrete reasoning is a decision-making process that relies on literal or concrete meanings of single pieces of information, such as prices or ingredients. (For instance, functional illiterate shoppers tend to buy items that display the cheapest prices, without regard to product volume.) Pictographic thinking is the attachment of literal, concrete meaning, rather than metaphorical, abstract meaning, to pictorial elements such as colors, fonts, package images. The authors highlight the pain of functionally illiterate shoppers as they attempt to decode written information and the anxiety of U.S. functionally illiterate consumers who fear their shortcomings will be unmasked. Such consumers develop coping 
strategies that facilitate their decision-making processes. For instance, they shop with family members, buy small amounts to keep within their budgets, or buy the same brands consistently. Other authors (e.g., Duhacheck 2005) confirm that functionally illiterate consumers use coping strategies to avoid negative emotions such as stress or shame.

However, literature on functionally illiterate consumers originates mostly in more developed countries; we have few insights on the shopping abilities of consumers in less developed countries. Given that research on functionally illiterate consumers focuses on their vulnerability and lack of power, we take a different approach by asking: What are consumers' abilities in developing countries? Are consumers in developing countries vulnerable? Can they be empowered through shopping?

\section{Consumer Empowerment, Vulnerability and Women}

Consumer empowerment as experienced by women may have begun with the opening of department stores in the West. Rappaport (2000) reports that the first department stores in the nineteenth and twentieth centuries were tailored for women, who then started to penetrate the marketplace. Some women enjoyed forms of empowerment in such places (Fiske 1989), mainly because department store employees (mostly men) would be devoted to assist women in their shopping. However, general discourse tends to describe shopping as an easy, frivolous activity (e.g., Zola 1883). Overall, this stream of literature describes the female shopper as a vulnerable consumer, blindly fascinated by store offers (e.g. Bowlby 1985). Dreiser (1900), for instance, describes an ingenuous young provincial woman who, arriving in Chicago, is unable to refrain from shopping. Similarly, Zola (1883) traces the life story of a young provincial woman who is captivated by the theatralization of the Bon Marché offer in Paris but who does not have enough purchasing power. But shopping difficulties are overall underestimated (Nava 1992).

This sense of frivolousness is in line with the Frankfurt School perspective, in which the consumer is regarded as a vulnerable victim seduced by the pleasures of consumption (e.g., Marcuse 1991). However, most advanced research in consumer power (e.g., Denegri-Knott, Zwick and Schroeder 2006) notes that the marketplace initiates empowerment (e.g., Papaoikonomou and Alarcón 2017). In particular, postmodern consumer research views the market as a place in which women can be active "consumers of change instead of passive suburban housewives" (Firat and Venkatesh 1995, p. 247).

Several works illustrate women's empowerment through market participation. Fiske (1989) compares the Western shopping woman to a guerilla girl who invests the public space and combats a dominant 
discourse about women confinement in private spheres. In developing contexts, Sandikci and Ger (2010) demonstrate how Turkish women found in veiling an avenue to navigate in various public spaces. Newcomb (2009) shows how a Moroccan singer manifests publicly her identities as a woman and singer, defying Moroccan conventions about women's morality and virtue. Lindridge, Peñaloza and Worlu (2016) show that Nigerian migrant women in Great Britain can gain power through consumption by participating in daily activities that empower them to adapt their family structures in relation to their husbands' patriarchal power. Overall, these examples provide contextual evidence that the marketplace offers women opportunities to empower and to subvert the social norms that confine them into private spheres. However, little consumer research investigates which consumption abilities are necessary for women to empower.

\section{Gender Roles and the Supermarket in Developing Contexts}

Some research suggests that the supermarket is a unique area in which gender roles may be negotiated (Dholakia 1999). In India, men make decisions about most family matters and women generally conform to their husbands' decisions. However, roles are inverted in the supermarket (Dholakia and Sinha 2005), where men appear to comply with their wives' decisions. They play the part of servile helpers who push their wives' carts. Traditionally, Indian women have been responsible for household provisioning. Today however, many Indian men carry out household provisioning alone, almost as often as women (Mitra 2015). Therefore, the supermarket appears to be a place that holds unique potential for negotiating gender roles in India.

Insights from Arab contexts suggest that similar negotiations between genders are taking place. Although Arab men traditionally have been in charge of household provisioning, observations from Libya note that an increasing number of women are patronizing recently opened supermarkets. Sehib, Jackson and Gorton (2013) uncover three factors that are facilitating the entrance of Libyan women into supermarkets: security, cleanness, and a low frequentation rate. They also note that many husbands approve of their wives' decisions to do the shopping. Once again, however, the authors do not explore precisely how these women have learned to shop.

Although existing literature in Arab contexts suggest avenues for gender role negotiations in supermarkets, they fail to provide a deep understanding of women's abilities to shop in supermarkets and do not investigate the outcomes in terms of women's empowerment. This paper aims to fill these gaps. In particular, we ask: Which abilities does the Arab 
woman develop in supermarkets? How can the Arab women use such abilities to empower?

\section{Research Site}

We chose to explore women's abilities to shop and the social outcomes related to gender roles in Morocco for two reasons. First, the Moroccan retail sector has experienced a dramatic restructuring over the past two decades. Second, gender segregation in Morocco is severe.

\section{Retail Context}

Morocco is a North African Muslim country, with an Arab and Berber population. Until 1990, the Moroccan retail context was fragmented and atomized, as it was in many developing countries (Kumcu and Kumcu 1987). Morocco has initiated a series of development programs that aim to increase its competiveness as it faces the challenges of globalization. Trade is a primary sector; it contributes $12.8 \%$ of the gross national product (GNP) and employs more than 1,200,000 Moroccans (Rawaj 2007). In particular, the strategic Rawaj Plan aims to provide consumers with powerful trade and distribution services that meet their specific needs (Rawaj 2007). It focuses on providing consumers with sufficient and diversified offers across a wide territorial area, supporting the modernization of local business, developing vibrant shopping areas, and ensuring the quality and diversity of available products.

The Moroccan food distribution system comprises large modern retail and wholesale supermarket chains, small supermarkets, convenience supermarkets, large self-service grocery stores, discounters, and "mom-and-pop" stores. The food distribution market represents 13\% of the country's GDP. Today, Morocco hosts 200 stores (larger than 980 square feet) and 17 hypermarkets (USDA 2015). The sector increased from 15 stores in 2000 to 224 in 2012 and aims to reach 600 in 2020. It represents a $15 \%$ share of national consumption (USDA 2015). Industry experts forecast that it will reach $30 \%$ of national consumption by 2025 .

The modern retail industry in Morocco is quite recent. The first hypermarket opened in 1990 in Rabat, the administrative capital. Since then, hypermarkets have expanded to Casablanca, Rabat, Marrakech, and other large cities; they now represent $15 \%$ of food retail sales.

Although hypermarkets are still difficult for non-motorized consumers to access, supermarkets within walking distance appear to be convenient alternative places for urban women to shop. Casablanca hosts 25 supermarkets of up to 25,000 square feet in size. Aggressive promotions, appealing prices, and discounts on a wide range of items attract lower-income consumers. Moroccan shoppers tend to buy more 
packaged products, and there is an increasing perception that food sold in supermarkets is safer and of higher quality (USDA 2015). Overall, however, prices are higher in supermarkets than in independent stores.

\section{Gender in Morocco}

Gender relations in Morocco are characterized by distinct sources of power. In the pursuit of our objectives, we limit our scope to orality, the social organization, and the political system (Sadiqi 2003).

Orality holds a unique place in Morocco, given that the country's mother tongues (local Arabic and Berber dialects) are mainly oral. Today, $38 \%$ of Moroccan women are illiterate (World Bank 2018). When orality comes from a man, it has a positive connotation. The power of a man's word is attested to by many deep relationships, such as marriage contracts, business contracts, and legacies after death (Sadiqi 2003). Women in Morocco do not possess authority over such contracts. When orality emanates from a woman, it has a negative connotation. It is often associated with gossip, rumors, and witchcraft (Sadiqi 2003).

The Moroccan social organization recognizes the family as the smallest unit of society. Unlike Western contexts, in which the individual self takes precedence over the collective self, Moroccan society functions primarily through the collective self, which generally refers to the family. The father is at the head of the family structure. His male lineage, which represents paternal authority, is founded on blood relations (NaamaneGuessous 2007). Women's freedoms are viewed as threats to the patriarchal structure (Sadiqi 2003). Therefore, women's appearances in public are carefully regulated. This regulation is reflected in female dress codes, speech, and family compounds; the high walls that surround homes are barriers that separate the public (more male) from the private (more female). The private, inner house is drastically separated from the public space. The male controls the female members of his family, both inside and outside his home (Naamane-Guessous 2007).

The political system in Morocco is also a male arena of power. Men discuss politics inside and outside the family. The notion of "jamaa" (group), which constitutes the basis of the Arab-Islamic tradition of social regulation, is viewed as male-only (Mernissi 2010); it asserts that men are meant to rule women and children. Women are thus almost absent from the sphere of political decision making. Attempts to push women forward in the political sphere are quite recent and relatively scarce. 


\section{Gender and Family in Morocco}

Household management and decision-making processes in Moroccan families reflect these social and political dimensions. A total of $62 \%$ of Moroccan women think that household management is a masculine task (Rachik et al. 2005); 9\% of women are deprived of any form of decision (Ministère de la Santé 2005). Overall, $79 \%$ of Moroccans think that a wife's obedience to her husband is necessary to maintain family harmony (Rachik et al. 2005), and 31\% of Moroccan women report being deprived of many forms of individual freedom. That is, their husbands control their outings, choose their female friends, proscribe the way they dress, and interfere in their choices to study, work, or use contraceptives. The rigid set of rules that infringe women's freedoms has been largely accepted and integrated by a vast majority of women: Two out of three Moroccan women think that it is legitimate for a man to beat his wife when she burns the meal, goes out without permission, neglects the children, or refuses sex on demand (Ministère de la Santé 2005).

In this context, Moroccan women who shop in supermarkets are practicing a "male" activity (household provisioning). They are not socialized during childhood to shop or make decisions about household provisioning, as is the case for most Western women (Roedder-John 1999). For instance, many do not possess the appropriate abilities to confront either self-service or written information. Thus, Moroccan women may encounter difficulties in making decisions related to household provisioning when they are alone in the supermarket.

\section{Methodology}

We gathered our data during a three-year ethnographic study of women in Casablanca, Morocco. Casablanca is the economic capital of Morocco. It was built by French colonial powers and modeled on the levels of freedom in France during the colonial era. Thus, the socio-cultural norms that dominate many of the cities in Morocco are not dominant in Casablanca (Newcomb 2009). Even so, there is ample evidence of strict gender role definitions that have been imported from other parts of the country. For instance, only $16 \%$ of women in Casablanca have a paid job (HCP 2013) and only $17 \%$ are family heads (HCP 2017). Moreover, $26 \%$ of Casablanca's population (age 10 years and older) cannot read or write (HCP 2017). The author has lived in Casablanca since childhood and has privileged access to the market by reason of cultural competence.

To gain meaningful understanding of the cultural setting and its relationship to marketplace meanings, we chose several shopping contexts, ranging from traditional stores and markets to modern 
supermarkets. We also participated in the daily lives of our informants, taking part in activities such as cooking, lunches, or family meetings. We accessed data and recorded human experiences in natural settings, using both participant and non-participant observation methods, because such methods facilitate access to "backstage" areas (Goffman 1959). In accordance with ethnographic conventions (e.g., Corbin and Strauss 2008), we took field notes during our observations, enriching them a few hours later with relevant details. In these enrichments, we paid attention to the researchers' emotional responses and interpretations, to reveal personal biases (Wallendorf, Belk and Heisley 1988). In total, we gathered 122 pages of handwritten field notes.

We supplemented our observations with 61 in-depth interviews to allow an emic perspective of women's participation in the evolving retail terrain. We selected informants according to established principles of variety and contrast (Miles and Huberman 1984). We started our fieldwork while interviewing informants that we knew before the investigation, then we enriched our sample while relying on snowball techniques and/or simply engaging a conversation with unknown women or men in supermarkets or other public spaces. In our sample, literacy levels varied from totally illiterate to $\mathrm{PhD}$-level; place of birth varied from rural to urban; age varied from 18 to 80 years; and occupation varied from housewife to medical doctor. Moreover, given that Moroccan women seem to enhance their identities and social negotiations when they speak French in public (Sadiqi 2003), we used a blend of Moroccan Arabic dialect and French. The dialect, though perceived to represent a low level of social sophistication, ensured emotional proximity between interviewer and informants. The interviews were translated from Arabic or French to English and transcribed on 1,029 pages.

We ran our analysis following the recommendations for ethnographic research (Arnould and Wallendorf 1994), moving back and forth between the empirical results and theories of empowerment and consumer abilities. We categorized, compared, and integrated the data through an iterative process. We considered iteratively the parts and the whole of each text, as well as comparing both individual texts and the entire data set. We used comparative and narrative techniques to provide empirical grounding for an emic representation that emerged from the data collected.

We sought to build particular insights on consumer abilities and their outcomes in terms of empowerment. The data analysis centered on women's reflective thoughts about their shopping experiences and related events with friends and relatives (Thompson, Locander and Pollio 1990). 
When informants related narrative accounts of shopping experiences, they moved back and forth among explanations, justifications, and their senses of how they managed to understand information or make decisions. Our observations of how women related to their families and relatives provided additional data. In line with recommendation for analysis of qualitative data (Spiggle 1994), the analysis of observations complemented our understanding of the outcomes in terms of women's empowerment.

We organize our findings as follows: First, we shed light on the various mechanisms that women use to develop abilities in terms of budgets, prices, packaging, and brands. We present our findings about abilities in the order of their importance, as expressed by our informants. Second, we reveal evidence of women's empowerment in families and communities and illustrate our findings with selected vignettes from the data that indicate women's abilities and power plays.

\section{Findings}

During interviews, our informants expressed their concerns about several themes that were particularly difficult for them. The first was coping with fixed budgets, which appeared to be a delicate task. They also noted their difficulties understanding prices. Finally, they identified the challenge of interpreting product information displayed on packaging; understanding brands seemed to be an issue. All these new abilities facilitate a sense of women empowerment, as all our informants were able to redefine their selves. They felt more skilled, and engaged in the family management.

\section{Managing a Budget}

Because many Moroccan female shoppers have limited budgets, they have developed specific strategies to deal with their financial limitations. However, such tasks get more complicated when shoppers are illiterate. Within the field of consumer research, some studies indicate confrontation strategies that involve the help of friends and supermarket employees (Viswanathan, Rosa and Harris 2005).

Managing a budget consists of two kinds of strategies: one related to the selection of the products, and another related to the total amount to be paid. Overall, Moroccan women shop with relatives who are educated or shop alone but rely on help from cashiers. For instance, Saida, a young law student goes shopping with her mother:

While we shop, we are constantly calculating. We take one item, we calculate, and we tell ourselves "this will raise the purchase amount up to this or that." That's it. Each time we choose a product, we add its price to the total. At a moment, we say "stop." When we 
reach the amount that we have in our pocket, that's it. (Saida, 20, student)

Saida's mother is illiterate and needs her daughter to read and translate the price tags. Saida's mother cannot count in dirhams (the local currency). She uses rials, a vernacular currency. One rial corresponds to five cents of a dirham (the smallest coin). In contrast, Saida is literate but has limited knowledge of brands and struggles to assess product quality. Although her mother chooses the items, Saida is responsible for the calculation. She adds to the total cost each time her mother put a new item in the cart. For Saida and her mother, the shopping strategy consists of performing two distinct tasks: the selection of the item, performed by the mother, and the calculation of the cost, performed by Saida. Previous studies of functionally illiterate Americans (Visanathan, Rosa and Harris 2005) have shown that functionally illiterate consumers often shop with their literate friends. In our context, the mother and daughter jointly perform two complementary roles in the shopping activity: the mother chooses, the daughter calculates.

Other illiterate informants have to shop alone though, so their adopted strategy consists of focusing on items rather than on the amounts to be paid. Aisha organizes her purchase to facilitate the selection of items and asks the cashier to help:

I put on the conveyer belt the products that I have in the cart. One by one. Following a specific order. I am organized. I begin with the most important. Because I always fill my trolley to the top. I like it chock full. At the cash till, I leave the things that are out of my budget. I say to the girl: "Here you are: I have 12,000 rials or 10,000 rials" and I ask her to stop me once I get to this amount. And it's great! I leave what I don't want because I began with the most important. I pay and I leave. (Aisha, 45, housecleaner)

Aisha and many informants describe their "most important" items invariably as "what we eat." Green tea, sugar, and flour constitute the nutritional basis of Morocco. Next are vegetables, with cosmetics at the bottom of the list. Shampoo is described as "the last thing we buy" when there is some cash left. Thus, informants such as Aisha do not try to calculate the amount to pay, even though researchers suggest it is a basic skill of supermarket shopping (Lave, Murtaugh and De La Rocha 1984; Walser-Luchesi 2011). We observed many female shoppers who behave like Aisha; they have developed an alternative strategy of putting items in order according to their importance to the household. 
Further, during her interview, Aisha manifested clear forms of pride, as she liked to provide many details on how she achieves to confront her lack of basic skills such as reading or understanding prices in dirhams. She presented herself as the one who would guide and lead during family shopping trips, although her husband or son would give the final decision on what to purchase.

Our findings show that budget management is a decision-making process that involves knowledge of market offerings and requires skills in calculation. Shopping is a planned activity with defined constraints (e.g., fixed budgets, manifested as the amount of cash in shoppers' pockets) and an invariant goal (e.g., meeting the most important needs).

Further, our findings show that as women achieve more shopping abilities, they develop a new sense of their selves as empowered in their capacity to participate actively in managing family expenses.

\section{Understanding Prices}

Beyond budgets, shoppers dedicate much time to interpreting and evaluating prices. Price is a key indicator of product quality when shoppers have little other knowledge of the product (Zeithaml 1988) or when the product is expensive (Olson 1977). But most informants confess that they have little knowledge of how to assess specific products such as coffee. Consider Leila and Khadija's comments:

I don't know [about coffee prices].... But if they are more expensive, there should be a good reason for that.... What do you think? [sigh] As the old adage says: "if you add water to your dough, add flour" (Leila, 35, high school teacher)

When the price increases, quality increases. That's why I always take coffee at an expensive price. I know that I won't regret it. Because if coffee is expensive, its quality will be better. (Khadija, 45 , housewife)

Informants such as Leila or Khadija report they do not know how prices are set. Coffee was introduced to Moroccan households at the end of the colonial period, about 70 years ago, and the market supply in coffee has increased slowly over the past 20 years. It is therefore not surprising that Moroccan women have no strong knowledge about buying coffee. "Coffee is always coffee, whereas there are so many different kinds of tea" says Khadija. Mint tea is the traditional hot drink in Morocco. For many generations, purchases of green tea and other products such as olive oil have been made by men. However, in Morocco, coffee is a new category, 
for which the purchase is not gendered, so women seem to have invested in it.

Previous research showed that shoppers in the West do not check prices before dropping routinely bought products in their trolleys (Barth and Bobot 2011; Dickson and Sawyer 1990). In contrast, our informants check all prices before making any decisions. They also seek to learn about prices and other product characteristics. For instance, Sabah, a housewife, remembers that she saw shampoos at 25 dirhams that "usually cost 38 dirhams." Zahra, a 40-year-old translator, and Soumia, a student of 23 years, keep their receipts in their handbags so they can review the prices and learn them by heart. Our informants also like to have long conversations with their friends about their shopping.

Our interviews thus show that informants have developed strategies to use prices in their decision-making processes. Meanwhile, they assert new forms of expertise in shopping, and empower in their social network. Indeed, their knowledge about prices nourishes many discussions among women. In the next section, we examine their strategies to assess and decode product packaging.

\section{Understanding Packaging Information}

The implementation of modern forms of retailing has provided many packaged products. For instance, flour, butter, spices, and sugar used to be sold in bulk; packaged flour first appeared in the late 1980s. Today, most independent sellers still do not supply packaged flour, pasta, spices, or sugar. Therefore, packaging and its related information are relatively new in the Moroccan context. For Khadija, the package fulfills a primary utilitarian function: it protects.

When it is about buying coffee, you may find many different shapes of packaging. The first thing that you have to check is the packaging that has to be resistant. It should impede air to get in, so that coffee does not rot. (Khadija, 45, housewife)

Although packaging fulfills this primary function, it also carries information that informants sometimes struggle to decode. Amina, Naima, Rajaa, Soumaya, and many others declare that they spend much time trying to decipher the ingredient lists on boxes. As a result, their shopping expeditions last more than three hours on average. Nour, a marketing student, describes how she understands pictographic information:

Huilor? It's sunflower oil. I can see the picture of a sunflower on the packaging.... It's a vegetable oil.... It's not like the other [Lesieur], which is not vegetable.... I don't know... (Nour, 22, student) 
Nour clearly expresses her difficulty in decoding pictographic packaging information. Although she is a master's student in marketing, she relies heavily on pictures displayed on packaging rather than not on the written information. When she does not see a plant on the oil bottle, she assumes that it is not vegetable (though Lesieur is made of plants). Nour's understanding of pictographic information reflects literature's portrayal of Western-context functionally illiterate consumers; even if a Moroccan shopper is literate, she may neglect written information.

For many, the information on packaging is difficult to understand. It blurs rather than facilitates the decision-making process. Aisha explains what she thinks about packaged green tea:

Last time I went to the supermarket, I found several opened packs [on the shelves]. It permitted me to smell and touch [the tea leaves] I think that it is good because you don't make any choice relying only on the sole package or price. Instead of choosing a packaging, we choose the quality of a product. It is the smell and the touch that permit you to tell if the product is of good quality or not. (Aisha, 45, housewife)

Aisha recalls using her traditional skills to assess the quality of green tea. She presses the leaves between her fingers and appreciates their smell. This process is quite distinct from the regular purchasing process in most Western supermarkets. In the Moroccan context, the packaging may be a barrier to proper assessment of products because it does not allow access to the content. As a result, many women open packages in supermarkets to assess the quality of flour, tea, or sugar, even if the packaging is made of transparent plastic. These product categories have been used commonly in Morocco for several generations. However, the shoppers tend not to inspect the content of new products such as coffee or laundry detergent.

Thus, many informants avoid packaged traditional foods, or they open the packages to ensure that the content has the expected characteristics. They replicate traditional market strategies for products that are sold in bulk (e.g., tea, olives, flour, sugar, spices) when they shop in the retail industry. Informants provided detailed descriptions of how they assess product quality, describing how products should taste or smell, or how they should feel crisp between the fingers. Such skills are highly valued by Moroccan shoppers. They assert that they prefer to access and compare product contents rather than rely on ingredient lists; the subject of shopping leads to long, enthusiastic conversations among women. 
Further, our data uncovers strong manifestation of women's power over the supermarket norms. For instance, while women keep up with traditional practices about selecting brands, they force supermarket managers to adapt displays of products.

\section{Learning about Brands}

Most informants declare that they are loyal to specific brands. Many have repeated successful experiences with particular brands, though some rely only on advice from relatives. For instance, after several attempts, Latifa has fixed her choice on several brands:

Over the years, I have been able to tell whether one or another product is of good quality and if it is worth its price.... A coffee is good if it is Carte Noire. If there is no Carte Noire available, I can assure you that nothing else enters my home. Same for jam: only Aicha. Cheese? Kiri. Butter? La Prairie. (Latifa, 40, housewife)

Latifa reports a common behavior, identified in prior literature: As shoppers multiply their shopping experiences, they acquire a certain level of skills and forms of familiarity with products (Alba and Hutchinson 1987). Latifa clearly recognizes that her repeated experiences in shopping have enhanced her ability to shop efficiently. When a new brand appears on the market, Latifa may consider buying it, but she is not willing to start from the beginning. She has dedicated energy and time to building her mental list of brands. In her words: "Do not change a winning team!" Over the years, Latifa has affiliated a specific brand with each product category. Today, she is loyal to her favorite brands.

Other informants, such as Rajaa, have chosen specific brands after following the advice of an expert shopper:

Once, I was at a friend's place. She is a general practitioner. She gave me a Danone [yogurt]. From that day, I always eat a lot of Danone because, if a doctor eats a Danone, it must be good for the health (Rajaa, 32, housewife)

Brand equity may be assessed through a first try before purchase or through experience. In any case, it is difficult to evaluate (Cochoy 2002; Nelson 1974). In Rajaa's story, the impact of health has to be believed rather than assessed. Thus, Rajaa relies on branding to enhance her confidence in her purchase decision (Aaker 1990).

Further, women like to demonstrate their empowering knowledge about brands and they gently mock the women who cannot differentiate between two brands. Ghita, a young student, laughs when she says: "There are people who ask for a Tide Omo [at the grocer's]!" 


\section{Women's Empowerment in Female Communities}

Women's new abilities in shopping have direct impacts on how they relate with other women. For instance, several informants report that they like to exchange with their colleagues about their brand experiences to increase their knowledge of market offerings. Overall, they assess the credibility of advice providers according to their profession (e.g., doctor, teacher) or age (Moroccan culture considers older women to be wise). However, young women also appear to advise their older friends. For instance, Malika, an illiterate housewife, likes to provide insights and information about new brands to her neighbor, who is 30 years older. Although shopping abilities are highly valued by our informants, the traditional framing of elders teaching youngsters, or the educated teaching illiterates, does not hold; we observed forms of socialization through shopping that entailed illiterates teaching the educated and young women advising older women. This is captured by Khadija's comment:

I look at contemporary women, how they do. Before, we would watch our parents and now we watch the contemporary woman. We try to know how they do and we do it [...] Actually, contemporary women are like experts, they are smart. They know everything about cooking and they know how to shop (Khadija, 80, housewife)

These remarks are far from unique. In the collective Moroccan imagination, the supermarket is a place for educated customers. It requires specific abilities (e.g., literacy).

Overall, our findings suggest that in Morocco, shopping abilities are highly valued; they lead to the negotiation of power plays among women. In the next section, we investigate the male perspective on women's abilities and their entry into the marketplace.

\section{Women's Empowerment and Men's Control of the Family}

Our female informants reported various impressions about the changes that are taking place in men's roles. Men are still in charge of important purchases such as meat or fish, but most now count on their wives to do daily household provisioning. For instance, Saida, a young law student, explains:

Saida: Sometimes, my brothers go to the supermarket, most of the time when I am not home. You know, my mother always asks me first to go shopping because ... they don't accept easily. You know how boys are! [laughs] 
Interviewer: And your father?

Saida: My father? Honestly, almost never! Most of the time, it's my mother or me, or both. We do the shopping. It's the tradition. The Moroccan tradition. Men don't do that [laughs]. [In Morocco] women do everything.

In her interview, Saida complained that she has to carry heavy bags and walk a long way home. She seemed to confirm the sudden change in male and female roles. The "tradition" she refers to is the emergent discursive framework related to household provisioning, in which women invest in supermarket shopping. For many, daily household provisioning has become naturally included in female tasks, even though it was strictly denied to the previous generation of women. Saida also recalls the dark side of shopping: It is a chore that men are happy to delegate to their wives and daughters. Saida seems to suggest that she has no choice about shopping, in contrast with her brothers who can either agree or refuse to go. Saida goes with her mother; she has integrated her frequent visits to the supermarket as a part of the scripted role of women in Moroccan society. For men, it seems that shopping is an option, whereas for women, it has become a duty.

Such observations would suggest that men have left women with more power. But our data uncovers strategies that men use to maintain control of household provisioning when they do not go shopping with their wives. For instance, they impose a strict control over the expenses or meet their wives at the till. Husbands thereby hold the power to validate purchases. However, many women view this strategy as an opportunity rather than a form of control. Fatima comments:

I love when they have special offers! When they have special offers, I buy as much as I can. And try to convince my husband. Even if my husband tells me that it is not an offer, just a few coins less. [laughs] But I don't listen to him. I don't pay, anyway [laughs]. (Fatima, 31, housewife)

Fatima's remark confirms that she has the power to choose the products. Whether her husband accepts her choice is of secondary importance to her. Fatima demonstrates that she is able to choose and that she can develop an argument to convince her husband. Furthermore, her remark shows that she does not consider the money spent as hers or even as family money; it is her husband's money. Thus, buying more at the supermarket is a way for her to benefit from her husband's money. In the past, women would have waited at home for their husbands to return with goods (Bourdieu 1980). 
Overall, our informants are conscious of their empowerment. Some like Ito (32, employee) or Nouria (36, housewife) claim their higher of input in the household decision making process.

[My husband], he is always there of course [when we do the shopping]. [The kids and I], we never went out with him. He let us choose what we want. He does not impose his choice (Fatima, 36, housewife)

It's me of course who does the shopping. I cannot trust my husband because I am always afraid that he may bring back home brands, goods that I don't want or that I don't trust. That's it! That's why I am in charge of grocery shopping. [...] My husband? He does not choose. He only pays at the till. (Ito, 32, employee)

Today, women like Nouria and Ito are proud to evoke their power to participate in the family decision-making process. Although they are not final decision makers, they have increased their participation in household provisioning. Yet, men have developed strategies to maintain control of their wives. Most of the time, they accompany their wives and pay at the till to limit their wives' (subtle) power.

\section{Conclusion}

Our investigation of Moroccan female shoppers sheds light on the various abilities that women use to do their household provisioning in supermarkets. Such abilities entail budget management, price and packaging understanding, and learning about brands. Women develop strategies to stay within the constraints of their budgets. They use prices to evaluate product quality and struggle to decode written information. They sometimes decide to bypass the packaging or reduce it to its primary function (e.g., protection of goods). Overall, as shoppers, Moroccan women both replicate strategies they use successfully in traditional stores (e.g., assessing product quality through smell or taste) and acquire new abilities (e.g., decoding information). They develop new routines after a series of successful experiences (e.g., taking a literate friend along, being loyal to specific brands). Our findings show that household provisioning is a serious business, and the abilities associated with it are efficient and highly valued.

The findings also indicate three theoretical contributions. First, we extend existing knowledge of ability and empowerment. Increased abilities have long been recognized as efficient tools for fostering social development (Sen 1999). In most developing countries, institutions are highly focused on developing literacy and promoting academic education 
to erode gender disparities (e.g., UNDP 2005). In Arab contexts, education campaigns aim at gender parity in primary and secondary school (e.g., CNDH 2015). However, these campaigns have had little impact on gender parity in the workforce or household management (HCP 2017). Our findings suggest that other forms of abilities (aside from basic literacy) can empower women. We do not mean that consuming or shopping are the most effective ways to achieve women's empowerment, but our results identify them as alternative sources of agency.

Thus, the nature of empowerment as uncovered in the present study relates to consumption and shopping. It extends beyond education and literacy skills and holds an instrumental value at the individual, family and societal levels.

At the individual level, shopping abilities permit the Moroccan woman to redefine herself. As she has extended her area of expertise to shopping, she is more inclined to see herself as a skilled agent in consumption.

We further argue that shopping abilities help Arab women to increase their inclusion and participation at the family level. As shown in our data, they assert a new role in the family provisioning: they have become family shopper. In sum, Moroccan women are empowered in their family: they slowly and delicately expand their abilities to participate in, negotiate with, influence, control and hold an accountable institution, that is, the family.

Further, women's empowerment impacts at the societal level. Overall, women are the ultimate agents of aggregate demand. They account for $70 \%$ of global spending (LSE Department for international Development 2014). While increasing their participation in household provisioning, the Arab women have the power to indirectly influence the level of the Moroccan economy and participate in the development of the Moroccan market. They further gain more visibility in the public space.

Second, our findings open a new perspective on consumer ability/vulnerability (e.g., Visconti 2015). Most supranational institutions tend to consider consumers who have difficulties choosing among products or obtaining and assimilating information as vulnerable (e.g., EU, OECD). In the marketplace, functionally illiterate consumers risk making bad purchases (e.g. Viswanathan, Rosa and Harris 2005). However, as our Moroccan research shows, women develop valuable abilities in supermarkets. This observation alludes to the notions of actual vulnerability and perceived vulnerability. Actual vulnerability occurs when consumers experience vulnerable states and give an account of what causes their vulnerability (Hamilton, Dunette and Piacentini 2016). 
Perceived vulnerability refers to a misconception of who is or can be vulnerable. In reality, perceived vulnerable consumers may not be so. In the specific case of Moroccan women, their vulnerability is of a perceived kind rather than actual. Indeed, their actual characteristics (e.g. functional literacy levels) may induce rapid conclusion about their vulnerable state. Moroccan women nevertheless demonstrate their ability to do their grocery shopping, and increase their participation in family matters. Their shopping experiences extend then to other areas than consumption, with important, but subtle, impact on women empowerment in their families and communities. Our findings thus shift the focus from consumer perceived vulnerability in the marketplace to women's empowerment in the social arena.

Third, our findings enrich knowledge on global and local dynamics (e.g., Firat 2016). Many globalization researchers emphasize its negative impacts on consumers in developing countries (e.g., Nguyen and Pham 2012). For instance, the spread of multinational retailers has increased consumerism (e.g. Ger and Belk 1996). But as we show, it also has contributed to the development of specific abilities that foster gender parity. Globalization provides arenas in which consumers can acquire abilities that lead to redistributions of power, redefinitions of people's lives, and reshaping of social structures.

Our research also has some limitations that indicate avenues for research. First, it refers to women and their power in families. It would be interesting to investigate how their empowerment relates to their children's socialization. In particular, researchers could examine mother-daughter relationships from the perspective of women's empowerment, by way of the market. Further, it would be interesting to investigate how these forms of socialization impact gender roles in the long run.

Second, we focus on shopping abilities. Researchers could investigate other abilities, such as matters related to the traditional nurturing role of women (e.g., cooking exotic foods, speaking languages) that may empower younger (vs. older) women in developing countries.

Third, our research is carried out in a patriarchal context; we know little about matriarchal structures. For instance, the Mosuo community in China does not recognize "fathers" or "husbands." An examination of the social outcomes of shopping ability development in matriarchal contexts might uncover distinct social dynamics and power (re)distributions between genders. 


\section{References}

Aaker, David (1990), "Brand extensions: The good, the bad, and the ugly", Sloan Management Review, 31, 47.

Abbes, Intissar and Isabelle Barth (2011), "Quand on negocie soi-même face au rayon," in Les petites histoires extraordinaires des courses ordinaires, Isabelle Barth and Blandine Anteblian, eds. Cormelles Le Royal: EMS Management \& Société.

Achrol, Ravi and Philip Kotler (2016), "Marketing's lost frontier: The poor", Markets, Globalization \& Development Review, 1 (1). https://doi.org/10.23860/MGDR-2016-01-01-03

Alba, Joseph W. and Westley Hutchinson (1987), "Dimensions of Consumer Expertise," Journal of Consumer Research, 13 (4), 41154. https://doi.org/10.1086/209080

Alvarez, and Michelle Lopez (2013), "From Unheard Screams to Powerful Voices: A Case Study of Women's Political Empowerment in the Philippines," $12^{\text {th }}$ National Convention on Statistics, EDSA, Mandaluyong City, October 1-2.

Anteblian, Blandine and Isabelle Barth (2011), "Apprendre à faire ses courses ou comment devenir adulte," in Les petites histoires extraordinaires des courses ordinaires, Isabelle Barth and Blandine Anteblian, eds. Cormelles Le Royal: EMS Management \& Société.

Arnould, Eric J. and Melanie Wallendorf (1994), "Market oriented ethnography: Interpretation building and market strategy formulation", Journal of Marketing Research, 31, 484-504. https://doi.org/10.2307/3151878

Amine, Abdelmajid and Najoua Lazzaoui (2010), "Shoppers' reactions to modern food retailing systems in an emerging country: The case of Morocco", International Journal of Retail and Distribution Management, 39, 562-81. https://doi.org/10.1108/09590551111148659

Barth, Isabelle and Lionel Bobot (2011), "“Bonjour, une baguette SVP, mais... bien cuitel": Le role de la repetition dans les courses ordinaires," in Les petites histoires extraordinaires des courses ordinaires, Isabelle Barth and Blandine Anteblian, eds. Cormelles Le Royal: EMS Management \& Société.

Bayeh, Endalcachew (2016), "The role of empowering women and achieving gender equality to the sustainable development of 
Ethiopia", Pacific Science Review B: Humanities and Social Sciences, 2 (1), 37-42. https://doi.org/10.1016/j.psrb.2016.09.013

Bourdieu, Pierre (1980), Le Sens Pratique. Paris: Les Editions de Minuit.

Bowlby, Rachel (1985), Just Looking. Consumer Culture in Dresier, Gissing and Zola. New York, NY: Routledge.

Brennan, Carol, Ivo Vlaev, Michael Blakemore and Nicola Smith (2017), "Consumer education and empowerment in Europe: Developments in theory and practice", International of Consumer Studies, 41 (2), 147-57. https://doi.org/10.1111/ijcs.12322

CNDH (2015), "Gender Equality and Parity in Morocco: Preserving and Implementing the Aims of the Constitution," Rabat: Conseil National des Droits de l'Homme.

Cochoy, Frank (2002), Une sociologie du packaging ou l'âne de Buridan face au marché. Paris: Presse Universitaires de France.

Corbin, Juliet and Anselm Strauss (2008), Basics of Qualitative Research, 3e. CA: Sage.

Denegri-Knott, Janice, Detlev Zwick and Jonathan E. Schroeder (2006), "Mapping consumer power: An integrative framework for marketing and consumer research", European Journal of Marketing, 40 (9/10), 950-71. https://doi.org/10.1108/03090560610680952

Dholakia, Nikilesh and Piyush Kumar Sinha (2005), "Observations on Observation in India's Dynamic Urban Market," Forum Qualitative Sozialforschung/ Forum: Qualitative Social Research, 6.

Dholakia, Ruby Roy (1999), "Going shopping: Key determinants of shopping behaviors and motivations", International Journal of Retail \& Distribution Management, 27, 154-65. https://doi.org/10.1108/09590559910268499

Dickson, Peter R. and Alan Sawyer (1990), "The price knowledge and search of supermarket shopper", Journal of Marketing, 54, 42-53. https://doi.org/10.2307/1251815

Dreiser, Theodore (1900), Sister Carrie. Mineola, NY: Dover Publications.

Duhachek, Adam (2005), "Coping: A multidimensional, hierarchical framework of responses to stressful consumption episodes", Journal of Consumer Research, 32, 41-53. https://doi.org/10.1086/426612 
Falk, Pasi and Colin Campbell (1997), The Shopping Experience. London: Sage.

Firat, Fuat (2016), "The dynamics of the local and the global: implications for marketing and development", Markets, Globalization \& Development Review, 1 (1). https://doi.org/10.23860/MGDR-201601-01-04

Firat, A. Fuat and Alladi Venkatesh (1995), "Liberatory postmodernism and the reenchantment of consumption", Journal of Consumer Research, 22, 239-67. https://doi.org/10.1086/209448

Fiske, John (1989), Reading the Popular. London: Routledge.

Ger, Guliz and Russel W. Belk (1996), "I'd like to buy the world a Coke. Consumptionscapes of the less affluent world," Journal of Consumer Policy, 19, 271-304. https://doi.org/10.1007/BF00411411

Goffman, Erving (1959), The Presentation of Self in Everyday Life. Garden City, NY: Doubleday.

Goldman, Arieh (1974), "Outreach of consumers and the modernization of urban food retailing in developing countries", Journal of Marketing, 38, 8-16. https://doi.org/10.2307/1250386

Hamilton, Kathy, Susan Dunnett and Maria Piacentini (2016), Consumer Vulnerability, Conditions, Contexts and Characteristics. London: Routledge.

HCP (2013), "La Femme Marocaine en Chiffres," Rabat: HautCommissariat au Plan.

HCP (2013), "Femmes Marocaines et Marché du Travail: Caractéristiques et Evolution," Rabat: Haut-Commissariat au Plan.

HCP (2017), "Note d'Information du Haut Commissariat au Plan à l'Occasion de la Journée Nationale de la Femme du 10 Octobre 2017," Rabat: Haut-Commissariat au Plan.

Kapchan, Deborah (1996), Gender on the Market. Moroccan Women and the Revoicing of Tradition. Philadelphia: University of Pennsylvania Press.

Kumcu, Erdogan and Ercan Kumcu (1987), "Determinants of food retailing in developing economies: The case of Turkey", Journal of Macromarketing, 7 , 26-40. https://doi.org/10.1177/027614678700700205 
Lave, Jean, Michael Murtaugh and Olivia de la Rocha (1984), "The Dialectic of Arithmetic in Grocery Shopping," in Everyday Cognition: Its Development in Social Context, Barbara Rogoff and Jean Lave, eds. Cambridge, MA: Harvard University Press, 67-94.

Lindridge, Andrew, Lisa Peñaloza and Preya Worlu (2016), "Agency and empowerment in consumption in relation to a patriarchal bargain: The case of Nigerian immigrant women in the UK", European Journal of Marketing, 50 (9/10), 1652-71. https://doi.org/10.1108/EJM-07-2011-0365

LSE Department for International Development (2014), Empowerment The Amartya Sen Lecture 2014. London: London School of Economics (accessed March 15, 2018), [available at http://www.Ise.ac.uk/assets/richmedia/channels/publicLecturesAnd Events/transcripts/20140606 1830 theAmartyaSenLecture2014 tr. pdf]

Malhotra, Anju, Jennifer Schulte, Payal Patel and Patti Petesch (2009), "Innovation for Women's Empowerment and Gender Equality" North Washington: ICRW, International Center for Research on Women.

Marcuse, Herbert (1991), "The New Forms of Control," in OneDimensional Man: Studies in the Ideology of Advanced Industrial Society (Second edition), 3-20. Oxon, UK and New York: Routledge.

Mernissi, Fatima (2010), Islam et Democratie. Paris: Albin Michel.

Miles, Matthew B. and Michael Huberman (1984), Qualitative Data Analysis. Berverley Hills: Sage.

Miller, Daniel (1998), A Theory of Shopping. Cambridge: Polity Press.

Ministère de la Santé (2005), "Enquête sur la Population et la Santé Familiale."

Mitra, Sounak (2015), "Nearly $80 \%$ of grocery shopping decisions taken by men, says study," Live Mint, [available at https://www.livemint.com/Consumer/34hH86yek1CWRwneK9CSM L/Nearly-80-of-grocery-shopping-decisions-taken-by-men-says.html

Naamane-Guessous, Soumaya (1990-2007), Au-Delà de toute Pudeur. La sexualité au Maroc. Casablanca: Eddif. 
Nava, Mica (1992), Changing Cultures: Feminism, Youth and Consumerism. London: Sage.

Nelson, Philip (1974), "Advertising as information", Journal of Political Economy, 82 (4), 729-54. https://doi.org/10.1086/260231

Newcomb, Rachel (2009), Women of Fès. Ambiguities of Urban Life in Morocco. Philadelphia: University of Pennsylvania Press.

Nguyen, Hieu P. and Huyen T. Pham (2012), "The dark side of development in Vietnam: Lessons from the killing of the Thi Vai River", Journal of Macromarketing, 32, 74-86. https://doi.org/10.1177/0276146711423666

Olson, Jerry C. (1977), "Price as an Informational Cue: Effects of Products Evaluations," in The Perception of Merchandise and Store Quality, Jacob Jacoby and Jerry Olson, eds. Lexington: DC Health.

Ozgun, Aras, Dicle Yurdakul and Deniz Atik (2017), "How do soap operas affects the poor? Experiences of Turkish women", Markets, Globalization \& Development Review, 2 (2). https://doi.org/10.23860/MGDR-2017-02-02-02

Palumbo, Rocco (2016), "Sustainability of well-being through literacy. The Effect of food literacy on sustainability of well-being", Agriculture and Agricultural Science Procedia, 8, 99-106. https://doi.org/10.1016/j.aaspro.2016.02.013

Papaoiconomou, Eleni and Amado Alarcón (2017), "Revisiting consumer empowerment: An exploration of ethical consumption communities", Journal of Macromarketing, 37 (1), 40-56. https://doi.org/10.1177/0276146715619653

Rachik, Hassan, Fatna Bourqia, Abdellatif Bencherifa and Mohamed Tozy (2005), "Rapport de Synthèse de l'Enquête sur les Valeurs. 50 ans de Développement Humain \& Perspective 2025," Rabat.

Rappaport, Erika D. (2000), Shopping for Pleasure: Women in the Making of London's West End. Princeton: Princeton University Press.

Rawaj (2007), "Rawaj, Vision 2020, Plan de développement du secteur commercial, Ministère de l'industrie et du commerce extérieur," Rabat.

Roedder-John, Deborah (1999), "Consumer socialization of children: A retrospective look at 25 years of research", Journal of Consumer Research, 26, 183-213. https://doi.org/10.1086/209559 
Sadiqi, Fatima (2003), Women, Gender, and Language in Morocco. Brill.

Sandikci, Özlem and Güliz Ger (2010), "Veiling in Style: How Does a Stigmatized Practice Become Fashionable?", Journal of Consumer Research, 37 (1), 15-36. https://doi.org/10.1086/649910

Sehib, Khaira, Elizabeth Jackson and Matthew Gorton (2012), "Gender, social acceptability and the adoption of supermarkets", International Journal of Consumer Studies, 37 (4), $379-86$. https://doi.org/10.1111/j.1470-6431.2012.01135.x

Sen, Amartya (1999), Development as Freedom. New York: Oxford University Press.

Spiggle, Susan (1994), "Analysis and interpretation of qualitative data in consumer research," Journal of Consumer Research, 21 (3), 491503. https://doi.org/10.1086/209413

Thompson, Craig J., William B. Locander and Howard R. Pollio (1990), "The lived meaning of free choice: An existential-phenomenological description of everyday consumer experiences of contemporary married women," Journal of Consumer Research, 17 (3), 346-61. https://doi.org/10.1086/208562

UNDP (2005), “Human Development Report 2005," New York: United Nations Development Program.

UNDP (2016), "Human Development Report 2016," New York: United Nations Development Program.

USDA (2015), "Gain Report," Rabat: United States Department of Agriculture, Foreign Agricultural Service.

Varman, Rohit and Russel W. Belk (2012), "Consuming postcolonial malls", Journal of Marketing Management, 28, 62-84. https://doi.org/10.1080/0267257X.2011.617706

Visconti, Luca M. (2016), "A conversational approach to consumer vulnerability: Performativity, representations, and storytelling," Journal of Marketing Management, 32, (3-4), 371-85. https://doi.org/10.1080/0267257X.2015.1122660

Viswanathan, Madhubalan, Manoj Hastak and Roland Gau (2009), "Understanding and facilitating the usage of nutritional labels by low literate consumers", Journal of Public Policy \& Marketing, 28 (2), 135-45. https://doi.org/10.1509/jppm.28.2.135 
Viswanathan, Madhubalan, Jose Antonio Rosa and James Edwin Harris (2005), "Decision making and coping of functionally illiterate consumers and some implications for marketing management", Journal of Marketing, 69 (1), 15-31. https://doi.org/10.1509/jmkg.69.1.15.55507

Wallendorf, Melanie (2001), "Literally literacy", Journal of Consumer Research, 27 (4), 505-11. https://doi.org/10.1086/319625

Wallendorf, Melanie, Russell Belk and Deborah Heisley (1988), "Deep meaning in possessions", Advances in Consumer Research, 15, 528-30.

Walser-Luchesi, Agnes (2011), "Quand chaque centime compte: Le role de l'hypersensibilité aux prix dans les courses ordinaires," in Les petites histoires extraordinaires des courses ordinaires, Isabelle Barth and Blandine Anteblian, eds. Cormelles Le Royal: EMS Management \& Société.

World Bank (2015), "Morocco, Mind the Gap: Empowering Women for a More Open, Inclusive, and Prosperous Society," Washington.

World Bank (2018), "Literacy rate, adult female (\% of females ages 15 and above)," [available https://data.worldbank.org/indicator/SE.ADT.LITR.FE.ZS]

Zeithalm, Valerie A. (1988), "Consumer perception of price, quality, and value: A means-end model and synthesis of evidence", Journal of Marketing, 52 (3), 2-22. https://doi.org/10.2307/1251446

Zola, Emile (1883), Au Bonheur des Dames. Kindle Edition. 